\title{
Effects of Local Administration of Propolis and Its Polyphenolic Compounds on Tumor Formation and Growth
}

\author{
Nada Oršolić, ${ }^{*, a}$ Svjetlana Terzić, ${ }^{b}$ Željko Minaljević, ${ }^{b}$ Lidija Šver,${ }^{c}$ and Ivan BašIĆ ${ }^{a}$ \\ ${ }^{a}$ Department of Animal Physiology, Faculty of Science, University of Zagreb; 10000 Zagreb, Rooseveltov trg 6, Croatia: \\ ${ }^{b}$ Croatian Veterinary Institute; Savska cesta 143, 10000 Zagreb, Croatia: and ${ }^{c}$ Faculty of Food Technology and \\ Biotechnology, Laboratory for Biology and Microbial Genetics, University of Zagreb; Kršnjavoga 25, 10000 Zagreb, \\ Croatia. Received February 21, 2005; accepted May 30, 2005
}

\begin{abstract}
Many dietary constituents are chemopreventive in animal models, and experiments with cultured cells are revealing various potential mechanisms of action. Compounds classified as blocking agents can prevent, or greatly reduce, initiation of carcinogenesis, or suppressing agents can act on cell proliferation. Caffeic acid (CA) and caffeic acid phenethyl ester (CAPE), members of the polyphenolic compounds, are present in high concentrations in medicinal plants and propolis, a natural beehive product. A water-soluble extract of propolis (WSDP) and two components of propolis, CA and CAPE were investigated for direct antitumor activity in vivo and in vitro. The local presence of $\mathrm{CA}$ and CAPE in the tissue caused a significant delay in tumor formation and increased life span 29.30 to $51.73 \%$, respectively. CA and CAPE, but not WSDP, significantly suppressed human HeLa cervical carcinoma cell proliferation in vitro. Based on these results, we postulate that the antitumor activity of polyphenolic compounds includes direct cytotoxic effects on tumor cells.
\end{abstract}

Key words water-soluble propolis extract; caffeic acid; caffeic acid phenethyl ester; mice; tumor growth

Chemoprevention is one of the most promising new approaches in cancer research, i.e., the administration of agents to inhibit, delay, or reverse the process of carcinogenesis. ${ }^{1)}$ The target of much research has been the discovery of natural and synthetic compounds that can be used in the prevention and/or treatment of cancer. Dietary flavonoids are known to affect the proliferation, differentiation, and apoptosis of cancer cells and may play an important role in cancer chemoprevention, especially for cancers of the gastrointestinal tract, because of their direct contact with food. ${ }^{2)}$ Many plants have shown various biologic activities like immunopotentiating and antitumor activities. Polyphenolics form a major part of the dietary antioxidant capacity of fruit and vegetables, and honey and propolis have been identified as chemopreventive agents for major human cancers. Honeybee propolis and its components caffeic acid (CA), caffeic acid phenethyl ester (CAPE), artepilin C, quercetin, naringenin, resveratrol, galangin, genistein and other are the most promising as antitumor agents. ${ }^{3-10)}$

Propolis (bee glue) is the generic name for the resinous substance collected by honeybees from various plant sources and used by bees to seal holes in their honeycombs, smooth out the internal walls, and protect the entrance against intruders. ${ }^{3)}$ It is rich in biochemical constituents, including mostly a mixture of polyphenols, flavonoid aglycones, phenolic acid and their esters, and phenolic aldehydes and ketones, terpenes, sterols, vitamins, amino acids, etc. ${ }^{3)}$ Propolis, a complex honeybee-hive product, possesses antiinflammatory, antiviral, immunostimulatory, and carcinostatic activities. ${ }^{11-19)}$ Two major active components of propolis are CA and CAPE, present in propolis at levels of $20-25 \%,{ }^{20)}$ they have many biological and pharmacologic activities, ${ }^{20-23)}$ including tumor growth suppression. ${ }^{24-26)} \mathrm{CAPE}$ is more potent in these activities than $\mathrm{CA}$, perhaps owing to its ability to pass through cell membranes more easily. It has been reported that CAPE may exhibit differential toxicity against cancer cells versus normal cells. CAPE inhibited the growth of type 5 adenovirus-transformed rat embryo fibroblasts more than it inhibited nonmalignant rat embryo fibroblast. ${ }^{17)}$ Subsequent studies suggested that CAPE-mediated growth inhibition depends on the transformed phenotype per $s e^{27)}$ and that it may be related to its modulation of oxidative processes in cells. For example, CAPE inhibited oxidative processes in $\mathrm{HeLa}$ cervical carcinoma cells better than or to a comparable degree as the potent nonsteroidal antiestrogen chemotherapeutic agent tamoxifen, (-)-epigallocatechin gallate, sarcophytol, and pento-o-galloyl- $\beta$-D-glucose. ${ }^{10,18,28)}$ Oxidative stress/ imbalance also is known to sensitize cells to die by apoptosis. Therefore, inhibition of cell proliferation and apoptosis are alternative responses to oxidative stress; the particular response may depend on cellular redox status at a given time. ${ }^{17,29)}$

The purpose of the present study was to examine whether the antitumor activity of water-soluble extract of propolis (WSDP), CA, or CAPE may be the result of direct cytotoxic activity on tumor cells.

\section{MATERIALS AND METHODS}

WSDP Treatment WSDP was prepared using the method described elsewhere. ${ }^{30)}$ Briefly, Croatian propolis from beehives kept on the outskirts of Zagreb, Croatia, or Brazilian propolis (CONAP, Belo Horizonte, Minas Gerais, Brazil) was extracted with $96 \%$ ethanol, which was filtered and evaporated to dryness in a vacuum evaporator. The resultant resinous product was added to a stirred solution of $8 \% \mathrm{~L}-$ lysine (Sigma Chemie, Deisenhofen, Germany) and freezedried to yield WSDP, a yellow-brown powder of Croatian or green powder of Brazilian propolis. Nikolov et al. ${ }^{30)}$ demonstrated that WSDP contains: caffeic acid $6.7 \% ; \gamma, \gamma$-dimethylallyl ferulate $1.2 \%$; isopentyl-2-enyl-caffeate $7.4 \%$; pentenyl caffeate $2.2 \% ; \gamma, \gamma$-dimethylallyl caffeate $8.5 \%$; pinobanksin $2.3 \%$; pinocembrin $9.2 \%$; pinobanksin-3-acetate $13.6 \%$; benzyl caffeate $0.4 \%$; galangin $7.8 \%$; $\beta$-phenyl ethyl caffeate $1.2 \%$; total flavonoids $32.9 \%$; and total esters of phenyl acid $20.9 \%$. Recent analyses using high-performance liquid chro- 
Table 1. HPLC Analysis of Water-Soluble Extracts of Propolis

\begin{tabular}{|c|c|c|c|c|c|c|c|}
\hline Preparation of WSDP & Caffeic acid & $\mathrm{CAPE}^{c)}$ & Naringenin & Chrisyn & Pinocembrin & Galangin & Total polyphenols \\
\hline Cr. WSDP ${ }^{a)}$ & 10.11 & 1.4 & 1.14 & 2.24 & 3.066 & 1.2 & 18.99 \\
\hline $\mathrm{Br} . \mathrm{WSDP}^{b)}$ & 1.71 & 1.7 & 0.43 & 5.44 & 5.46 & 3.07 & 17.81 \\
\hline
\end{tabular}

a) Croatian water-soluble extract of propolis. b) Brazilian water-soluble extract of propolis. c) Caffeic acid phenethyl ester.

matography (HPLC) from our laboratory have revealed that our preparations of WSDP specimens from either Croatian or Brazilian propolis contained w/v total polyphenols $18.99 \%$ and $17.81 \%$, respectively (Table 1 ).

WSDP was refrigerated under sterile conditions. Before use, WSDP was dissolved in distilled water, and mice were administered WSDP at the exact site of subcutaneous injection of tumor cells at doses of $50 \mathrm{mg} \mathrm{kg}^{-1}$ and $150 \mathrm{mg} \mathrm{kg}^{-1}$ body weight.

CAPE CAPE was obtained by esterification of CA with phenethyl alcohol (molar ratio $1: 15$ ) in benzene (refluxing, 3-4 d, water removed by Dean-Stark trap). Following this procedure, excess phenethyl alcohol was removed by Kugelröhr distillation $\left(60^{\circ} \mathrm{C},<0.1 \mathrm{mmHg}\right)$ to give pure CAPE, mp $126-128^{\circ} \mathrm{C}$, needles (benzene or $\mathrm{H}_{2} \mathrm{O}$ ), $40 \%$ yield. All properties of natural and synthetic CAPE were identical. ${ }^{31)}$ It was administered to mice at the exact site of subcutaneous injection of tumor cells at doses of $50 \mathrm{mg} \mathrm{kg}^{-1}$ and $150 \mathrm{mg} \mathrm{kg}^{-1}$. CAPE was dissolved in ethanol and further diluted with water. The final concentration of ethanol was less than or equal to $0.1 \%$. Ethanol $(0.1 \%)$ was used in the control group. At this concentration of ethanol, no significant change in cytotoxicity was observed in preliminary experiments.

CA (3,4 Dihydroxycinnamic Acid) CA was purchased from Aldrich-Chemie, Milwaukee, WI, U.S.A. CA was administered to mice at the exact site of subcutaneous injection of tumor cells at doses of $50 \mathrm{mg} \mathrm{kg}^{-1}$ and $150 \mathrm{mg} \mathrm{kg}^{-1}$. CA was dissolved in ethanol and further dilutions were made in water. The final concentration of ethanol was less than or equal to $0.1 \%$. Ethanol $(0.1 \%)$ was used in the control group.

Animal Studies Animal studies were carried out according to the guidelines in force in the Republic of Croatia (Law on the Welfare of Animals, N. N. \#19, 1999) and in compliance with the Guide for the Care and Use of Laboratory Animals, DHHS Publ. (NIH) \#86-23. Male and female CBA inbred mice from our conventional mouse colony were used. In all experiments, mice were of the same sex and were approximately 3 months old at the initiation of the study. The animals were housed not more than 5 to a cage and were maintained on a pellet diet and water ad libitum. Experimental groups were composed of 7-10 mice each.

Tumor A transplantable mammary carcinoma (MCa) of spontaneous origin in a CBA mouse was used. The tumor is weakly immunogenic for syngeneic recipients as shown by different methods in vivo. ${ }^{32)}$

Tumor-Cell Suspension Single-cell suspensions were prepared by digestion of tumor tissue with trypsin, which contained no visible regions of necrosis or hemorrhage. ${ }^{33)}$ Each suspension was passed through a stainless steel mash (200 wires/inch), centrifuged three times at $24 \boldsymbol{g}$ for $5 \mathrm{~min}$ in saline and then resuspended in medium RPMI-1640 (Institute of Immunology, Zagreb) supplemented with 5\% serum from normal syngeneic mice. Viable cells were counted in a hemocytometer. Viability determined by observing the ability of intact cells to exclude Trypan blue dye and by phasecontrast microscopy was found to be greater than $95 \%$.

Production of Subcutaneous Tumor in the Leg $\mathrm{Tu}$ mors in the hind leg was generated by subcutaneous injection of $10^{5}$ tumor cells. The growth of tumor at the site of tumor cell inoculation was checked every day thereafter. During the experimental period mice were weighed every $5 \mathrm{~d}$.

Survival Analysis For the survival analysis, CBA mice were inoculated with $1 \times 10^{5} \mathrm{MCa}$ cells at exact site of subcutaneous injection of different doses of WSDP or its polyphenolic compounds at doses of 50 or $150 \mathrm{mg} \mathrm{kg}^{-1}$. The endpoint of experiments was determined either by spontaneous death of the animals or by elective killing (with $\mathrm{CO}_{2}$ gas) of the animals because of signs pain or suffering according to established criteria. Results are expressed as percentage of mean survival time of treated animals over mean survival time of the control group (treated versus control, $\mathrm{T} / \mathrm{C} \%$ ). The percentage of increased lifespan (ILS\%) was calculated according the formula: ILS\% $=(\mathrm{T}-\mathrm{C}) / \mathrm{C} \times 100$ where $\mathrm{T}$ represents mean survival time of treated animals and $\mathrm{C}$ represents mean survival time of the control group. By UN National Cancer Institute criteria, T/C exceeding $125 \%$ and ILS exceeding $25 \%$ indicate that the drug has significant antitumor activity. ${ }^{34)}$

Cell Lines The experiments were performed using human cervical carcinoma cells (HeLa). The average doubling time in $\log$ phase was about $20 \mathrm{~h}$ for HeLa cells. Cells were grown in monolayer cultures in plastic disposable Petri dishes (Falcon) in minimal essential medium (MEM) with $10 \%$ bovine calf serum. Cell cultures were incubated at $37^{\circ} \mathrm{C}$ in a humid atmosphere containing $5 \% \mathrm{CO}_{2}$ in air.

${ }^{3} \mathbf{H}$-Thymidine Incorporation into DNA Inhibition of ${ }^{3} \mathrm{H}$-methyl thymidine $\left({ }^{3} \mathrm{H}-\mathrm{TdR}\right)$ was studied using the pulselabeling method. Proliferating cells were incubated for $24 \mathrm{~h}$, and then different concentrations of WSDP, CA, or CAPE were added over different periods of time $(24,48,72 \mathrm{~h})$. After 24,48 , or $72 \mathrm{~h}$, cells were exposed to ${ }^{3} \mathrm{H}-\mathrm{TdR}(1.0 \mu \mathrm{Ci})$ for $3 \mathrm{~h}$. Then the cells were harvested onto glass fibber filters with an automatic harvester (Skarton, Norway). Filters were dried and the radioactivity was quantified using liquid scintillation spectrophotometry (LKB, Wallace). Results were expressed as percentages of untreated cell counts.

Statistics To determine the significance of difference between two averages, we used Student's $t$-test. Treatment dosespecific survival curves were calculated according to the Kaplan-Meier method, and the log-rank test was used to compare survival curves using the statistical software pacKage STATA 7.0 (Stata Press, College Station, TX, U.S.A.). 


\section{RESULTS}

Direct Antitumor Activity of WSDP and Related Polyphenolic Compounds Figure 1 and Table 2 summarize whether the presence of WSDP, CA, or CAPE in the tissue administered locally at the exact site of tumor cell inoculation influenced tumor formation and the survival rate of mice. Test compounds $(50$ or $150 \mathrm{mg} / \mathrm{kg}$ ) were injected subcutaneously into the footpads. Immediately after injection mice received subcutaneous injection containing $10^{5}$ viable tumor cells. The appearance of tumor was checked daily. Figure 1 shows that tumor formation was dose dependently delayed in mice treated with polyphenolic compounds. While all mice in the control group developed tumors within $22 \mathrm{~d}$ after tumor cell inoculation and died between 28 and $40 \mathrm{~d}$ thereafter, the development of tumors in treated mice and their survival time were delayed; survival of mice treated with CA or CAPE was significantly longer than that of those treated with WSDP. The presence of WSDP, CA or CAPE in the tissue of tumor cells inhibited tumor growth and ILS of mice by 18.1 to $51.74 \%$ (Table 2 ).

To compare toxicity profiles of the test components, we administered them subcutaneously at dose of 50 and 150 $\mathrm{mg} / \mathrm{kg}$ to nontumor-bearing mice. No group of animals receiving WSDP preparations, CA, or CAPE lost weight (data not shown). Moreover, in tumor-bearing mice treated with CA or CAPE, a delay in tumor growth and significant increase in survival without mortality or body weight loss was noted (Table 3).

Effects of Test Compounds on DNA Synthesis of HeLa Cells To study whether the antitumor effects of test compounds achieved in vivo were due to direct cytotoxicity on tumor cells or through other mechanisms of antitumor action, we investigated their effects on the growth of HeLa cells in vitro. Proliferating HeLa cells were exposed to different concentrations of WSDP, CA, or CAPE for 24 or $48 \mathrm{~h}$. The cells were then allowed to incorporate ${ }^{3} \mathrm{H}-\mathrm{TdR}$, an indication of newly synthetized DNA, for $3 \mathrm{~h}$. Table 4 shows the results. WSDP did not affect the growth of HeLa cells. Growth inhibition by CA or CAPE on HeLa cells was dose dependent.

\section{DISCUSSION}

We previously described the nonspecific immunostimulatory and antimetastatic effects of WSDP. ${ }^{33)}$ Recently, we have shown that oral administration of WSDP or CA inhibited subcutaneous tumor growth whether given before tumor cell inoculation or after stabilization of tumor growth. The life span of mice treated with WSDP and CA before tumor cell inoculation was significantly prolonged compared with controls. ${ }^{35)}$ To determine direct effects on tumor growth, we injected the test compounds locally and immediately thereafter at the site of tumor cell inoculation. The data shown in Table 2 and Fig. 1 indicate that the presence of CA or CAPE in the tissue of tumor cells inhibited tumor growth and increased the survival of treated animals by $29.30 \%$ and $51.74 \%$, respectively, while WSDP was less effective. Moreover, the local presence of CA and CAPE in the tissue caused a significant delay in tumor formation ( $p=0.0127$, or $p=0.000$, logrank test); delay of tumor formation could be the main reason for the ILS of mice treated with CA or CAPE. It was shown
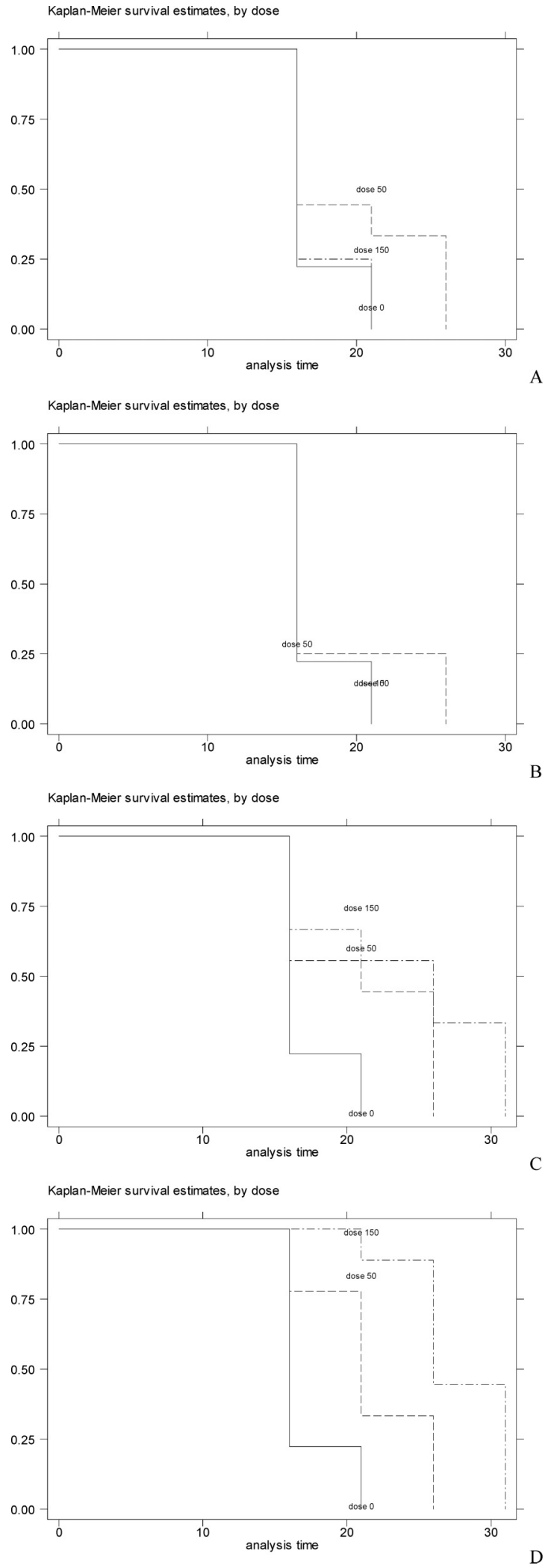

Fig. 1. Sequential Observation of Palpable Mammary Tumor in CBA Mice Inoculated with $10^{5}$ Mammary Carcinoma Cells at the Exact Site of Subcutaneous Injection of Water-Soluble Extract of Croatian WSDP (A) or Brazilian WSDP (B), Caffeic Acid (C) or Caffeic Acid Phenethyl Ester (D)

Tumor cells were introduced immediately after test compound injection. Each group comprised 8 to 9 mice. A, B: Result of the log-rank test shows that dose did not significantly influence onset of mammary tumor formation in mice treated with Croatian or Brazilian WSDP $(p=0.1312$ or $p=0.448)$ compared with control. C, D: Tumor formation of mice treated with CA or CAPE was significantly delayed $(p=0.0127$ or $p=0.000$, log-rank test). 
Table 2. In Vivo Antitumor Activity of WSDP, CA, and CAPE ${ }^{a}$

\begin{tabular}{|c|c|c|c|c|c|c|}
\hline Group & Mice per group & $\begin{array}{l}\text { Dose } \mathrm{mg} / \mathrm{kg} \\
\text { (s.c.) }\end{array}$ & $\begin{array}{l}\text { Survival time } \\
\text { range (days) }\end{array}$ & $\begin{array}{l}\text { Median survival } \\
\text { time (days) }\end{array}$ & ILS $\%$ & $\mathrm{~T} / \mathrm{C} \%$ \\
\hline Control & 9 & - & $28-40$ & 35.66 & - & - \\
\hline \multirow[t]{2}{*}{ Croatian WSDP } & 9 & 50 & $35-51$ & 42.11 & 18.09 & 118.09 \\
\hline & 8 & 150 & $30-37$ & 33.875 & -5.01 & 94.99 \\
\hline \multirow[t]{2}{*}{ Brazilian WSDP } & 8 & 50 & $31-48$ & 42.375 & 18.83 & 118.83 \\
\hline & 9 & 150 & $40-46$ & 43.44 & 29.30 & 121.817 \\
\hline \multirow[t]{2}{*}{ CA } & 9 & 50 & $37-55$ & 46.11 & & 129.30 \\
\hline & 9 & 150 & $34-59$ & 46.55 & 30.538 & 130.538 \\
\hline \multirow[t]{2}{*}{ CAPE } & 9 & 50 & $42-50$ & 46.66 & 30.846 & 130.846 \\
\hline & 9 & 150 & $36-80$ & 54.11 & 51.738 & 151.738 \\
\hline
\end{tabular}

a) CBA mice were injected subcutaneously with $10^{5}$ mammary carcinoma cells at the exact site of subcutaneous injection of different doses of WSDP, CA, or CAPE immediately after injection of test compounds. T/C, treated versus control. ILS \% (increased life span $\%)=(\mathrm{T}-\mathrm{C}) / \mathrm{C} \times 100$. T, mean survival days of treated group; C, mean survival days of control group.

Table 3. Changes in Body Weight of Mice Treated with WSDP and Its Polyphenolic Compounds

\begin{tabular}{|c|c|c|c|c|c|c|c|c|}
\hline \multirow{2}{*}{ Group } & \multirow{2}{*}{$\begin{array}{c}\text { Dose } \\
(\mathrm{mg} / \mathrm{kg})\end{array}$} & \multicolumn{6}{|c|}{$\%$ weight change on days } & \multirow{2}{*}{$\begin{array}{c}\text { No. of } \\
\text { toxic deaths }\end{array}$} \\
\hline & & 0 & 5 & 10 & 15 & 20 & 25 & \\
\hline Control & - & 20.15 & +0.13 & +0.30 & +0.1 & -2.3 & -2.9 & 0 \\
\hline \multirow[t]{2}{*}{ Cr. $\mathrm{WSDP}^{a)}$} & 50 & 21.28 & +0.27 & +0.75 & +0.90 & +0.57 & +0.31 & 0 \\
\hline & 150 & 20.5 & +0.22 & +0.77 & +0.35 & -0.10 & -0.70 & 0 \\
\hline \multirow[t]{2}{*}{ Br. WSDP ${ }^{b)}$} & 50 & 21.17 & +0.17 & +0.83 & +0.93 & +0.47 & +0.93 & 0 \\
\hline & 150 & 20.82 & +0.15 & +0.64 & +0.67 & +0.53 & +0.78 & 0 \\
\hline \multirow[t]{2}{*}{$\mathrm{CA}$} & 50 & 19.96 & +0.19 & +0.94 & +1.03 & +1.05 & +1.15 & 0 \\
\hline & 150 & 21.3 & +0.15 & +0.77 & +0.90 & +1.10 & +1.25 & 0 \\
\hline \multirow[t]{2}{*}{ CAPE } & 50 & 20.7 & +0.2 & +0.75 & +0.78 & +1.07 & +1.17 & 0 \\
\hline & 150 & 20.51 & +0.10 & +0.95 & +1.0 & +1.09 & +1.13 & 0 \\
\hline
\end{tabular}

a) Croatian water-soluble extract of propolis. b) Brazilian water-soluble extract of propolis.

Table 4. Effects of WSDP, CA, or CAPE on ${ }^{3} \mathrm{H}$-Thymidine Incorporation into DNA of HeLa Cells

\begin{tabular}{|c|c|c|c|c|c|}
\hline Treatment $^{a)}$ & $\begin{array}{l}\text { Time }(\mathrm{h}) \text { of } \\
\text { incubation with } \\
\text { test compounds }\end{array}$ & $\begin{array}{l}\text { Concentration } \\
(\mu \mathrm{g} / \mathrm{ml})\end{array}$ & $\begin{array}{l}\text { Incorporation of } \\
{ }^{3} \mathrm{H} \text {-thymidine } \\
(\mathrm{cpm} / \mathrm{min} \pm \text { S.E. })^{b)}\end{array}$ & $\begin{array}{c}\text { Percent }(\%) \\
\text { of control }\end{array}$ & $\begin{array}{c}\text { Student's } \\
t \text {-test }\end{array}$ \\
\hline - & 24 & - & $2080.70 \pm 79.47$ & 100 & \\
\hline \multirow[t]{3}{*}{ WSDP } & 24 & 25 & $2226.02 \pm 133.02$ & 106.8 & \\
\hline & & 50 & $2283.86 \pm 166.51$ & 109.76 & \\
\hline & & 100 & $2099.78 \pm 139.92$ & 100.9 & \\
\hline \multirow[t]{3}{*}{ Caffeic acid } & 24 & 6.25 & $1665.36 \pm 27.19$ & 83.5 & $p<0.05$ \\
\hline & & 12.5 & $1461.76 \pm 76.19$ & 62.7 & $p<0.01$ \\
\hline & & 25 & $1391.18 \pm 53.99$ & 25 & $p<0.001$ \\
\hline \multirow[t]{3}{*}{ CAPE } & 24 & 6.25 & $2135.51 \pm 73.46$ & 102.6 & \\
\hline & & 12.5 & $1697.89 \pm 84.45$ & 81.6 & $p<0.05$ \\
\hline & & 25 & $650.41 \pm 125.69$ & 31.25 & $p<0.001$ \\
\hline- & 48 & - & $3528.28 \pm 154.01$ & 100 & \\
\hline \multirow[t]{3}{*}{ WSDP } & 48 & 25 & $4069.80 \pm 342.58$ & 115.35 & \\
\hline & & 50 & $4121.94 \pm 230.92$ & 116.32 & $p<0.05$ \\
\hline & & 100 & $5152.16 \pm 338.27$ & 146.02 & $p<0.001$ \\
\hline \multirow[t]{3}{*}{$\mathrm{CA}$} & 48 & 6.25 & $1568.83 \pm 267.10$ & 70.7 & $p<0.001$ \\
\hline & & 12.5 & $1353.54 \pm 166.83$ & 50.3 & $p<0.001$ \\
\hline & & 25 & $929.34 \pm 100.99$ & 19.9 & $p<0.001$ \\
\hline \multirow[t]{3}{*}{ CAPE } & 48 & 6.25 & $2668.14 \pm 101.51$ & 75.6 & $p<0.001$ \\
\hline & & 12.5 & $2066.40 \pm 75.42$ & 58.56 & $p<0.001$ \\
\hline & & 25 & $1699.89 \pm 22.38$ & 48.16 & $p<0.001$ \\
\hline
\end{tabular}

a) Proliferating HeLa cells were incubated for $24 \mathrm{~h}$, and then different concentrations of test compounds were added. b) After exactly 24 or $48 \mathrm{~h}$, cells were exposed to ${ }^{3} \mathrm{H}-$ thymidine for $3 \mathrm{~h}$, harvested, and counted with a scintillation counter. Incorporation of ${ }^{3} \mathrm{H}$-thymidine into DNA of HeLa cells is expressed as mean count per minute (cpm/min) S.E. of nine samples. c) Significantly different from the untreated controls. 
that animals treated with immunostimulants resist, to various degrees, subsequent inoculation of tumor cells as evidenced by the reduced "tumor take," slowed growth of the tumors, and prolonged survival of recipients. ${ }^{25,36-38)}$ Scheller et al. ${ }^{37)}$ reported that the ethanolic extract of propolis is capable of increasing survival of mice bearing Ehrlich carcinoma and suggested that immunostimulant activity of propolis may be associated with macrophage activation and enhancement of macrophage phagocytic activity. Matsuno ${ }^{38)}$ reported that various components of propolis have potent antiinflammatory and antitumor activity. In addition, Hayashi et al. ${ }^{36}$ ) showed that quercetin chalcone and modified citrus pectin reduced the growth of solid colon-25 primary tumor when given to mice. So far, no experiment has been performed on the local treatment of solid $\mathrm{MCa}$ with polyphenolic compounds. Kimoto et al. ${ }^{25}$ ) reported that artepilin C (a component of propolis) has cytostatic and cytotoxic effects on various malignant tumor cells in vitro and in vivo and that it activates the immune system, especially by increasing the number of macrophages and their phagocytic activity as well as the number of lymphocytes, and has direct antitumor activity. This paper presents data showing that direct cytotoxic effects of polyphenolic compounds but not of WSDP are likely to be the most important mechanism of antitumor activity of the test compounds in vivo and in vitro. Our previous data suggested that propolis and its compounds stimulate macrophages and reduce the number of $\mathrm{MCa}$ metastases in CBA mice. ${ }^{2433)}$ Polyphenolic compounds also delayed tumor formation and increased survival when administered locally at the exact site of tumor cell inoculation (Table 2, Fig. 1). These findings suggest that $\mathrm{CA}$ and $\mathrm{CAPE}$ suppress $\mathrm{MCa}$ growth via an other mechanism(s) different from those mentioned above. These mechanisms include the ability of CA and CAPE to inhibit DNA synthesis in tumor cell cultures (Table 4) and the induction of apoptosis of tumor cells. ${ }^{39,40)}$ Furthermore, the ability of CA and CAPE to induce apoptosis suggests their potential use in clinical trials as therapeutic anticancer agents. It is likely that the antitumor activity of CA or CAPE is highly dependent on dose; higher doses exhibited more potent antitumor activity, while WSDP did not affect the growth of cells in in vitro studies. It has been demonstrated $^{40,41)}$ that higher doses of CA or CAPE interfered with cell processes such as enzyme and glutathione levels; this may induce cells death or apoptosis. ${ }^{39,40)}$ Moreover, selective effects of CAPE on transformed cells compared with normal cells were observed; CAPE has been observed to induce apoptosis in transformed cells ${ }^{17)}$ and exhibit cytotoxicity in oral cancer cells. ${ }^{42)}$ Human/rat tumor cell lines displayed a significantly greater sensitivity to the action of CAPE than analogous normal lines. ${ }^{31)}$ Differential cytotoxicity toward tumor cells has been demonstrated through modulation of the cellular redox state. ${ }^{17)}$ A study by Coffey et $a{ }^{43)}$ showed that thiol depletion can effectively activate caspase 3 and subsequently induce cancer cell apoptosis. Treatment with CAPE caused rapid activation of caspase 3 after $4 \mathrm{~h}$, downregulation of Bcl-2 expression after $6 \mathrm{~h}$, and upregulation of Bax expression after $16 \mathrm{~h}$ in human leukemic HL-60 cells. ${ }^{11)}$ By altering the cellular redox status, CAPE inhibited several critical growth-regulating signaling pathways such as receptor tyrosine kinases and blocked the DNA binding of transcription regulators, such as NF- $\kappa \mathrm{B} .{ }^{44)}$ The cellular mechanisms of the effect are not known but could be related to the various biological effects of CA and CAPE: antioxidant properties ${ }^{17-19)}$; inhibition of many enzymes, including NADPH oxidase, ${ }^{41)}$ cyclooxygenase and lipoxygenase ${ }^{15)}$; and inhibition of cellular enzymes involved in signal transduction. ${ }^{13,23,41)}$ We have shown that WSDP may be associated with the activation of macrophages, which leads to an increase in their lytic capacity against tumor cells. ${ }^{33,39)}$ Macrophage toxicity to tumor cells can be mediated through direct contact with the cells or through the production of soluble factors, or both. The antitumor activity of WSDP may be the result of a different specific mechanism(s) of polyphenolic compounds present in WSDP as compared with individual polypenolyc compounds given alone. Our results and those of others suggest that both Croatian and Brazilian WSDP extracts exhibit similar activities and that in different samples, different combinations of substances are essential for the biologic activity of propolis. Thus, in spite of the difference in their chemical composition, propolis from all regions ranging from the temperate zone to tropical areas exhibited similar biologic properties. ${ }^{7,21,45)}$ Park et al. ${ }^{46)}$ demonstrated that green Brazilian propolis, in addition to having the same components as the European, contains coumaric and ferulic acid, isosakuretin, and kaempferide and the quantity of pinobaksin was much higher than in European propolis. ${ }^{46)}$

To conclude, the present results show that the antitumor activity of WSDP is not a result of direct cytotoxicity to tumor cells, while the polyphenolic compounds CA and CAPE present in propolis affect tumor growth through the inhibition of DNA synthesis and exert direct antitumor effects by close contact with tumor cells.

\section{REFERENCES}

1) Heo M. Y., Sohn S. J., Au W. W., Mutat. Res., 488, 135-150 (2001)

2) Kuo S. M., Cancer Lett., 110, $41-48$ (1996).

3) Ghisalberti E., Bee World, 60, 59-84 (1979).

4) Walker P., Crane E., Apidologie, 18, 327-334 (1987).

5) Bankova V., Christov R., Stoev G., Popov S., J. Chromatogr., 607, 150 - 153 (1992).

6) Bankova V., Christov R., Popov S., Z. Naturforsch. C, 49, 6-10 (1994).

7) Marcucci M. C., Apidologie, 26, 83-99 (1995).

8) Matsuno T., Matsumoto Y., Saito M., Morikawa J., Z. Naturforsch. C, 52, 702-704 (1997).

9) Kimoto T., Aga M., Hino K., Koya-Miyata S., Yamamoto Y., Micallef M. J., Hanaya T., Arai S., Ikeda M., Kurimoto M., Anticancer Res., 21, $221-228$ (2001).

10) Akao Y., Maruyama H., Matsumoto K., Ohguchi K., Nishizawa K., Sakamoto T., Araki Y., Mishima S., Nozawa Y., Biol. Pharm. Bull., 26, 1057-1059 (2003).

11) Chen Y. J., Shiao M. S., Hsu M. L., Tsai T. H., Wang S. Y., J. Agric. Food Chem., 49, 5615-5619 (2001).

12) Luo J., Soh J. W., Xing W. Q., Mao Y., Matsuno T., Weinstein I. B., Anticancer Res., 21, 1665-1671 (2001).

13) Nomura M., Kaji A., Ma W., Miyamoto K., Dong Z., Mol. Carcinog., 31, 83-89 (2001).

14) Choi Y. H., Lee W. Y., Nam S. Y., Choi K. C., Park Y. E., Int. J. Mol. Med., 4, 29-32 (1999).

15) Shureiqi I., Chen D., Lotan R., Yang P., Newman R. A., Fischer S. M., Lippman S. M., Cancer Res., 60, 6846-6850 (2000).

16) Ogata S., Miyake Y., Yamamoto K., Okumura K., Taguchi H., Biosci. Biotech. Biochem., 64, 1075-1078 (2000).

17) Chiao C., Carothers A. M., Grunberger D., Solomon G., Preston A. G., Barrett C. J., Cancer Res., 55, 3576-3583 (1995).

18) Chen Y. J., Shiao M. S., Wang S. Y., Anti-Cancer Drugs, 12, 143-149 (2001). 
19) Vieira O., Escargueil-Blanc I., Meilhac O., Basile J. P., Laranjinha J., Almeida L., Salvayre R., Negre-Salvayre A., Br. J. Pharmacol., 123, 565-573 (1998)

20) Greenaway W., Scaysbrook, T., Whatley F. R., Proc. R. Soc. London B, 232, 249-272 (1987).

21) Banskota A. H., Tezuka Y., Adnyana I. K., Ishii E., Midorikawa K., Matsushige K., Kadota S., Phytomedicine, 8, 16-23 (2001).

22) Xiang T., Xiong Q. B., Ketut A. I., Tezuka Y., Nagaoka T., Wu L. J., Kadota S., Planta Medica, 67, 322-325 (2001).

23) Weyant M. J., Carothers A. M., Bertagnolli M. E., Bertagnolli M. M., Clin. Cancer Res., 6, 949-956 (2000).

24) Bašić I., Oršolić N., Tadić Z., Macedo Fereire Alcici N., Brbot Šaranović A., Bendelja K., Krsnik B., Rabatić S., "17th International Cancer Congress,” Rio de Janeiro, 1998, pp. 63-75.

25) Kimoto T., Arai S., Kohguchi M., Aga M., Nomura Y., Micallef M. J., Kurimoto M., Mito K., Cancer Detect. Prev., 22, 506-515 (1998).

26) Mahmoud N. N., Carothers A. M., Grunberger D., Bilinski R. T., Churchill M. R., Martucci C., Newmark H. L., Bertagnolli M. M., Carcinogenesis, 21, 921-927 (2000).

27) Su Z. Z., Lin J., Prewett M., Goldstein N. I., Fisher P. B., Anticancer Res., 15, 1841-1848 (1995).

28) Bhimani R., Frenkl K., Proc. Am. Assoc. Cancer Res., 32, 126-130 (1991).

29) Burdon R. H., Free Radic. Biol. Med., 18, 775-794 (1995).

30) Nikolov N., Marekov N., Bankova V., Popov S., Ignatova R., Vladimirova I., Bulgarian Journal of Patology Applied, 79903/28, 05, (1987).

31) Grunberger D., Banerjee R., Eisinger K., Oltz E. H., Efros L., Caldwell M., Estevez V., Nakanishi K., Experientia, 44, 230-232 (1988).
32) Bašić I., Varga E., Period. Biol., 81, 335-337 (1979).

33) Oršolić N., Bašić I., J. Ethnopharmacol., 84, 265-273 (2003).

34) Plowman J., Dykes D. J., Hollingshead M., Simpson-Herren L., Alley M. C., "Anticancer Drug Development Guide: Preclinical Screening, Clinical Trials, and Approval," ed. by Teicher B., Humana, Totowa, NJ, 1995, p. 101.

35) Oršolić N., Terzić S., Šver L., Bašić I., J. Sci. Food Agric., 85, 363 370 (2005).

36) Hayashi A., Gillen A. C., Lott J. R., Altern. Med. Rev., 5, 546-552 (2000).

37) Scheller S., Krol W., Swiacik J., Owczarek S., Gabrys J., Shani J., Z. Naturforsch., 44c, $1063-1065$ (1989).

38) Matsuno T., Z. Naturforsch., 50, 93-97 (1995).

39) Oršolić N., Horvat Knežević A., Šver L., Terzić S., Bašić I., Ethnopharmacol., 94, 307-315 (2004).

40) Oršolić N., Bendelja K., Brbot-Šaranović A., Bašić I., Period. Biol., 106, 367-372 (2004).

41) Frenkel K., Wei H., Bhimani R., Ye J., Zadunaisky J. A., Huang M. T., Ferraro T., Conney A. H., Grunberger D., Cancer Res., 53, 12551261 (1993).

42) Lee Y. J., Liao P. H., Chen W. K., Yang C. Y., Cancer Lett., 153, 5156 (2000).

43) Coffey R. N., Watson R. W., Hegarty N. J., O’Neill A., Gibbons N., Brady H. R., Fitzpatrick J. M., Cancer, 88, 2092-2104 (2000).

44) Natarajan K., Singh S., Burke T. R., Jr., Grunberger D., Aggarwal B. B., Proc. Natl. Acad. Sci., U.S.A., 93, 9090-9095 (1996).

45) Burdock G. A., Food Chem. Toxicol., 36, 347-363 (1998).

46) Park Y. K., Alencar S. M., Aguiar C. L., J. Agric. Food Chem., 50, $2502-2506$ (2002). 